\title{
REFLEXÕES ACERCA DA EXECUTIVIDADE DAS SENTENÇAS DE IMPROCEDÊNCIA EM AÇÕES DECLARATÓRIAS NEGA- TIVAS
}

\author{
REFLECTIONS ON THE EXECUTIVITY OF REFUSAL JUDGMENTS \\ IN NEGATIVE DECLARATORY ACTIONS
}

\author{
Rosalina Moitta Pinto da Costa"
}

\begin{abstract}
RESUMO
O trabalho analisa a executividade das sentenças de improcedência de demandas declaratórias de inexistência de obrigação, procurando demonstrar que, não obstante a tendência doutrinária e jurisprudencial, não se pode afirmar que toda sentença de improcedência de demanda declaratória de inexistência de obrigação é um título executivo judicial. Utilizando-se como opção metodológica a pesquisa bibliográfica e a jurisprudência do Superior Tribunal de Justiça, inicia-se o estudo analisando a evolução da ampliação das hipóteses de tutela declaratória para, no tópico seguinte, enfrentar-se o movimento que chegou ao Superior Tribunal de Justiça, desencadeando a revisão na doutrina clássica de que toda sentença declaratória é um título executivo judicial. Conclui-se que nem toda sentença de improcedência de demanda declaratória de inexistência da obrigação é título executivo judicial porque isso geraria uma antinomia em nosso sistema processual, com violação à garantia do devido processo legal, pois não se pode admitir a execução de uma sentença, que não chegou a examinar todos os aspectos da existência ou inexistência direito exequendo, e, ao mesmo tempo, limitar sua defesa no momento da impugnação ao cumprimento de sentença.
\end{abstract}

PALAVRAS-CHAVE: Ação Declaratória de Improcedência. Título Executivo Judicial. Executividade.

\begin{abstract}
The paper analyzes the enforceability of the sentences of dismissal of declaratory claims of non-obligation, trying to demonstrate that, despite the doctrinal and jurisprudential tendency, it can not be said that any sentence of dismissal of a declaratory claim of nonobligation is a title executive. Using as a methodological option the bibliographic research and the jurisprudence of the Superior Court of Justice, the study begins analyzing the evolution of the expansion of the hypotheses of declaratory tutelage. In the next topic, to face the movement that reached the Superior Court of Justice, triggering the revision in the classic doctrine that every declaratory sentence is a judicial enforceable title. It is concluded that not every decision of inadmissibility of a declaratory claim of non-existence of the obligation is a judicial enforceable title because this would generate an antinomy in our procedural system, in violation of the guarantee of due process, since it can not be admitted the execution of a sentence, which failed to examine all aspects of the existence or non-existence of the right to do so, and at the same time to limit its defense at the time of the impugnation to compliance with the sentence
\end{abstract}

KEYWORDS: Declaration of Inadmissibility. Judicial Executive Title. Executivity.

* Doutora em Direito das Relações Sociais (PUC/SP). Mestre em Direito Agrário (UFPA). Especialista em Direito Ambiental (UFPA). Especialista em Direito Civil e Processo Civil (ESMPA). Professora de Direito Processual Civil da Universidade Federal do Pará (UFPA). Professora Permanente do Programa de Pós-Graduação Stricto Sensu em Direito da Universidade Federal do Pará (UFPA). Coordenadora do Grupo de Pesquisa “Inovações no Processo Civil” (UFPA/ CNPQ). Mediadora certificada pelo CNJ/CCMJ.. E-mail: rosalina.costa@hotmail.com. 
SUMÁRIO: 1. INTRODUÇÃO 2. NATUREZA E EVOLUÇÃO DAS HIPÓTESES DE TUTELA DECLARATÓRIA 3. EFICÁCIA EXECUTIVA DAS SENTENÇAS MERAMENTE DECLARATÓRIAS 4. REFLEXÕES ACERCA DA SENTENÇA DE IMPROCEDÊNCIA DE DEMANDA DECLARATÓRIA DE INEXISTÊNCIA DE OBRIGAÇÃO 5. CONCLUSÃO. REFERÊNCIAS.

\section{INTRODUÇÃO}

Na clássica tripartição das sentenças, como somente as sentenças condenatórias conteriam o comando capaz de compelir o devedor à realização de uma prestação, caberia apenas a essas a qualidade de título executivo. As declaratórias e constitutivas limitar-se-iam à determinação de certeza ou a instituição de uma nova situação jurídica, respectivamente, mas não teriam força executiva para determinar a realização coativa em juízo de qualquer prestação.

Essa situação passou a ser alterada ainda no CPC de 1973, e o art. 515, I, do CPC de 2015, ao reconhecer como título executivo não apenas as sentenças, mas todas "as decisões ${ }^{1}$ proferidas no processo civil que reconheçam a exigibilidade de obrigação de pagar quantia, de fazer, de não fazer ou de entregar coisa”, manteve o entendimento que já se firmara desde a Lei $n^{\circ} 11.232$, em 2005, ao introduzir o art. 475-N, de ampliar a força executiva para decisões declaratórias e constitutivas, além, portanto, das sentenças condenatórias ${ }^{2}$.

As significativas inovações que atingiram as tutelas declaratórias levaram, sob a liderança do Superior Tribunal de Justiça, o entendimento de que, em face do seu caráter dúplice, toda sentença declaratória, desde que contenha todos os elementos configuradores da obrigação exigível, que, para tanto, haverá naturalmente de ser certa e líquida, é título executivo judicial, incluindo-se, aí, sentenças declaratórias de inexistência de obrigação, quando julgadas improcedentes.

$\mathrm{O}$ trabalho questiona a afirmação de que toda sentença de improcedência de demanda declaratória de inexistência de obrigação é um título executivo judicial. Para tanto, parte-se do estudo da evolução da ampliação das hipóteses de tutela declaratória para, a seguir, analisar-se a executividade das sentenças declaratórias, abordando o processo histórico que levou o Superior Tribunal de Justiça a provocar uma revisão na doutrina clássica de que toda sentença declaratória é um título executivo judicial.

1 Por “todas as decisões”, entende-se as decisões relativas às tutelas de urgência ou de evidência, ou quaisquer outras que, no curso do processo, imponham à parte prestações certas e líquidas, de imediato exigíveis. Nesse sentido: THEODORO JÚNIOR, 2017, p. 29; WAMBIER, DIDIER JR., TALAMINI, DANTAS, 2015, p. 1.323; WAMBIER, CONCEIÇÃO, RIBEIRO, MELLO, 2016, p. 933-934

2 THEODORO JÚNIOR, 2017, p. 29; NEVES, 2018, p. 1.110; SANTOS, 2017, p. 30. 
Ao final, enfrenta-se o extremado posicionamento do STJ de que toda sentença de improcedência de demanda declaratória de inexistência da obrigação é título executivo judicial, pois não se pode admitir a executividade de uma sentença que não chegou a examinar todos os aspectos da existência ou inexistência direito exequendo e, ao mesmo tempo, permitir a limitação da admissibilidade da impugnação ao cumprimento de sentença. Conclui-se que tal posicionamento além de gerar uma contradição em nosso sistema processual, representa violação à garantia do devido processo legal.

Utiliza-se, como opção metodológica, a pesquisa bibliográfica e jurisprudencial, desenvolvida por meio de análise de textos normativos e de decisões proferidas pelo Superior Tribunal de Justiça.

\section{NATUREZA E EVOLUÇÃO DAS HIPÓTESES DE TUTELA DE- CLARATÓRIA}

A função da tutela declaratória é fundamentalmente a eliminação da incerteza em torno da existência ou inexistência de uma determinada relação jurídica, a qual tem origem, não no descumprimento de uma obrigação, mas na dúvida a respeito da existência de relação jurídica. Já disse Ovídio que "o juiz não vai além de um juízo de pura realidade, não ultrapassando o domínio do ser ou do não ser: não profere qualquer juízo de valor" 3 .

Essa incerteza que enseja a ação declaratória não é a incerteza do autor, mas a incerteza jurídica, i.e., a incerteza da própria lide ${ }^{4}$. Não basta o autor estar em estado de dúvida a respeito de seu direito, mas haverá de demonstrar que a incerteza provém de alguma circunstância externa e objetiva, diversa e mais grave do que a simples incerteza subjetiva, ou puramente acadêmica ${ }^{5}$.

A tutela declaratória não cria, nem modifica ou extingue qualquer direito ou relação jurídica, mas limita-se a declarar o que existe ou o que não existe, no domínio do direito, visando evitar que a incerteza sobre uma relação jurídica produza dano. Em razão disso a doutrina sempre apontou sua função preventiva. Como disse Carnelutti, as ações declaratórias não são lides de dano, mas de probabilidade de dano ${ }^{6}$, "procura-se evitar sua consumação por meio do acertamento preventivo. $\mathrm{O}$ juiz intervém para que a incerteza atual não provoque uma escolha futura de conduta indevida" ${ }^{7}$.

\footnotetext{
3 SILVA, 1996, p. 134.

4 “ (...) A incerteza não deve residir, necessariamente, no espírito do autor, ela deve resultar do próprio conflito de interesses (...)” (REsp 435.125/SP, Rel. Ministro Humberto Gomes De Barros, $1^{\text {a }}$ T., DJ 19/12/2002, p. 341)

5 LIEBMAN, 1992, p. 172.

6 CARNELUTTI, 1971, p. 152.

7 THEODORO JÚNIOR, 1996, p. 93.
} 
A segurança perseguida pela via da ação declaratória é alcançada pela coisa julgada. Ainda que esse valor esteja presente nas outras ações, ele é o traço marcante e distintivo na ação declaratória ${ }^{8}$, pois a certeza jurídica, conforme já advertiu Chiovenda, é um bem da vida, perseguível, como qualquer outro bem juridicamente relevante, através do processo. O reconhecimento pelo adversário jamais poderia produzi-lo em igual grau, porque nenhuma segurança se iguala à coisa julgada que se obtém através da sentença. Nesse caso o processo é a única fonte autônoma e possível do bem procurado9.

Excetuando-se o caso único de autenticidade ou de falsidade documental, somente uma relação jurídica, i. é., a relação entre pessoas ou entre pessoas e coisas, regulada pelo direito, pode ser objeto da ação declaratória, sendo incabível a declaração de simples fato, sobre simples questão de direito, por mais intrincada que seja ou sobre a existência de futura relação jurídica ${ }^{10}$. Muito menos é meio idôneo para fazer consultas sobre a vigência ou o sentido de norma jurídica, por isso não se deve confundir o fato com suas consequências jurídicas, pois somente estas podem ser objeto da declaratória ${ }^{11}$.

Esta concepção se manteve no Código de Processo Civil de 2015, cujo art. 19, praticamente reproduziu a redação anterior (art. $4^{\circ}$ do CPC de 1973). A incerteza que enseja o cabimento da tutela declaratória deve ser objetiva (incerteza criada por fatos concretos que indiquem haver ameaça ao direito que se pretende ver declarado) e atual (não bastando a mera possibilidade futura remota de violação ao direito $)^{12}$.

A tutela meramente declaratória deve recair sobre relações jurídicas, mais precisamente sobre a existência ou inexistência de um direito subjetivo (a uma prestação) ou potestativo (a uma modificação jurídica). Para tanto, é necessário que o juiz reconheça um fato ou conjunto de fatos e a eles subsuma norma jurídica para apurar se emergiu ou não direito subjetivo ou potestativo ${ }^{13}$.

Ainda sob a vigência do CPC de 1973, a jurisprudência do STJ passou a alargar a interpretação do art. $4^{\circ}$ do CPC de 1973 (art. 19 do CPC/2015), admi-

8 LOPES, 1995, pp 55-64.

9 CHIOVENDA, 1960, pp. 41-2.

10 LOPES, 1995, p. 57; BARBI, 1996, p. 71.

11 A doutrina se debatia sobre as matérias que poderiam ser objeto da ação declaratória. João Batista Lopes e Celso Agrícola Barbo chegaram a fazer um rol das situações onde era incabível a ação declaratória: "declaratória de posse, declaratória de validade ou invalidade de contrato de compra e venda, declaratória de simulação em negócio jurídico, declaratória para esclarecimento sobre preço de mercadoria adquirida" (LOPES, 1995, pp. 59-79); "declaração acerca da existência de arrendamento rústico ou urbano, declaração sobre direito sucessório em testamento de pessoa ainda não falecida, declaração de sanidade mental, declaração de que a mercadoria entregue é igual a amostra, declaração que o trabalho está de acordo com as regras e que foi executado pelo autor, porque se trata de fato" (BARBI, 1996, p. 71)

12 SICA, 2014,p. 449.

13 SICA, 2014, p. 450. 
tindo a demanda declaratória em situações não abrigadas expressamente pelo dispositivo, como por exemplo, a demanda meramente declaratória de validade ou invalidade de negócio ou ato jurídico, o que redundou na edição da Súmula 181, assim redigida: “é admissível ação declaratória, visando a obter certeza quanto à exata interpretação de clausula contratual" ${ }^{14}$.

Do mesmo modo, o STJ, exceptuando à vedação às ações declaratórias de mero fato, editou a súmula 242 afirmando que "Cabe ação declaratória para reconhecimento de tempo de serviço para fins previdenciários", passando a admitir a ação declaratória para negar a existência da relação jurídica que se define legal e constitucionalmente como "união estável ${ }^{15}$, bem como passou a ser tranquilo o entendimento de que a demanda meramente declaratória se sujeita à prescrição quando houver pretensão condenatória ${ }^{16}$.

Observa-se que o âmbito de incidência das tutelas declaratórias foi paulatinamente sendo ampliado, o que é compatível com o comando do art. $5^{\circ}$, XXXV, da Constituição federal, que permite o acesso ao Poder Judiciário contra qualquer "ameaça a direito" 17.

\section{EFICÁCIA EXECUTIVA DAS SENTENÇAS MERAMENTE DECLA- RATÓRIAS}

Sob a égide do CPC de 1973 preponderava o entendimento de que a sentença declaratória não era suscetível de execução uma vez que "ela esgota sua finalidade com o fato de tornar certo, indiscutível o direito" ${ }^{18}$.

Como não há sentenças puras, conforme afirmou Pontes de Miranda ${ }^{19}$, salvo os efeitos executivos extraídos da sentença declaratória, como custas e ho-

14 “(...) I. Admissível a ação declaratória para o exame e interpretação de cláusulas contratuais, visando ao afastamento de ilegalidade nelas eventualmente existentes. II. Aplicação da Súmula n. 181 do STJ. III. Recurso Especial conhecido e provido”. (REsp 273.181/MG, Rel. Ministro Aldir Passarinho Junior, $4^{\mathrm{a}}$ T., DJ 11/12/2000, p. 211).

15 “(...) A viúva tem legitimidade para promover ação declaratória de inexistência de união estável do seu falecido marido com a ré. - A convivência entre duas pessoas é um fato; a união estável é conceito jurídico que pode ou não definir essa relação. Cabe ação declaratória para reconhecer a inexistência da relação jurídica que se conceitua legalmente como união estável. - Recurso não conhecido” (REsp 328.297/RJ, Rel. Ministro Ruy Rosado de Aguiar, 4ª T., DJ 18/02/2002, p. 457).

16 O STJ firmou o entendimento no sentido de que a ação declaratória pura é imprescritível, salvo quando houver pretensão condenatória-constitutiva em que está sujeita à prescrição do Decreto 20.910/1932. Nesse sentido: REsp 1721184/SP, Rel. Ministro Herman Benjamin, $2^{\mathrm{a}}$ T., DJe 16/11/2018; AgRg no REsp 696.743/RJ, Rel. Ministro Fernandes, 6 a T., DJe 22/03/2010; AgRg no REsp 646.899/AL, Rel. Ministro Herman Benjamin, 2 ${ }^{\mathrm{a}}$ T., DJe 17/06/2009; AgRg no REsp 616.348/MG; REsp 959.096/MG, Rel. Ministra Eliana Calmon, 2ª T., DJe 08/05/2009; REsp 750.620/ES, Rel. Ministro João Otávio De Noronha, 2ª T., DJ 25/04/2007 p. 305.

17 SICA, 2014, p. 451

18 TORNAGHI, 1974, p. 92.

19 Segundo PONTES DE MIRANDA (1976, p. 124), nenhuma ação ou sentença nasce pura, mas constitui um conjunto de eficácias, devendo ser classificada segundo a sua eficácia principal. 
norários passíveis de execução, se o vencedor do pleito meramente declaratório pretendesse promover a execução forçada seria obrigado a propor nova ação (desta vez, condenatória), cujo deslinde ficaria simplificado em razão da coisa julgada que se constitui na ação anterior.

Esse entendimento não foi alterado pela omissão do CPC de 1973, quando não reproduziu a regra do art. 290 do CPC de 1939 que claramente afirmava que a sentença declaratória não constituiria título executivo ${ }^{20}$, pois, no seu art. $20^{21}$, acabou mantendo a mesma diferença entre a ação declaratória e condenatória, ao determinar que se a parte tivesse interesse de agir para ingressar com a ação condenatória, mas optasse pela ação declaratória, ficaria sujeita às restrições da sua exigibilidade, ou seja, poderia ajuizar a ação declaratória, mas não teria eficácia executiva, o que fez com que a ausência do dispositivo do CPC de 1939 não tivesse nenhum efeito prático.

Tais concepções, contudo, foram abaladas em 2003 por força do ensaio de Teori Zavaski publicado na revista da faculdade de direito ${ }^{22}$, onde afirmava que a sentença declaratória tem executividade. Defendeu o autor que a sentença que acolhe a ação declaratória traz em si a declaração não apenas da existência, mas também da exigibilidade da prestação, não se podendo negar a eficácia executiva se estiverem presentes todos os elementos identificadores da obrigação (sujeitos, prestação, liquidez, exigibilidade), pois isso representaria atentado ao direito constitucional à tutela executiva. Disse o autor:

ao legislador ordinário não é dado negar executividade a norma jurídica concreta, certificada por sentença, se nela estiverem presentes todos os elementos identificadores da obrigação (sujeitos, prestação, liquidez, exigibilidade), pois isso representaria atentado ao direito constitucional à tutela executiva, que é inerente e complemento necessário do direito de ação. Tutela jurisdicional que se limitasse à cognição, sem as medidas complementares necessárias para ajustar os fatos ao direito declarado na sentença, seria tutela incompleta. E, se a norma jurídica individualizada está definida, de modo completo, por sentença, não há razão alguma, lógica ou jurídica, para submetê-la, antes da execução, a um segundo juízo de certificação, até porque a nova sentença não poderia chegar a resultado diferente do da anterior, sob pena de comprometimento da garantia da coisa julgada, assegurada constitucionalmente. Instaurar a cognição sem oferecer às partes e principalmente ao juiz outra alternativa de resultado que não um já prefixado, representaria atividade meramente burocrática e

Todas sentenças contêm certos elementos de outra espécie que, em determinadas circunstâncias podem exigir alguma provisão jurisdicional posterior, sejam elas condenatórias declaratórias ou constitutivas.

20 Art. 290 do CPC de 1939: "na ação declaratória, a sentença que passar em julgado valerá como preceito, mas a execução do que houver sido declarado somente poderá promover-se em virtude da sentença condenatória".

21 Art. 20 do CPC de 1973: "é admissível a ação declaratória ainda que tenha ocorrido violação ao direito"

22 ZAVASCKI, 2003a, p. 226. O ensaio também foi publicado Repro, v. 208 (ZAVASKI, 2003b, p. 45-46). 
desnecessária, que poderia receber qualquer outro qualificativo, menos o de jurisdicional.

Portanto, repetimos: não há como negar executividade à sentença que contenha definição completa de norma jurídica individualizada, com as características acima assinaladas" 23 .

$\mathrm{O}$ ensaio da teoria, associado às decisões que proferiu ${ }^{24}$, provocou profundas reflexões no meio acadêmico acabando por levar a alteração do Código de processo Civil de 1973, quando a Lei $\mathrm{n}^{\circ}$ 11.232, em 2005, introduziu o art. 475-N, estabelecendo que é título executivo judicial a "sentença proferida no processo civil que reconheça a existência de obrigação de fazer, não fazer, entregar coisa ou pagar quantia". Se reconhecer é o mesmo que declarar, não precisava mais que o juiz trouxesse a palavra condeno pois da própria lei passou a vir a executividade.

A sentença que reconhece o direito - declara - passou a ser um título executivo por expressa determinação legal.

A executividade das sentenças declaratórias, contudo, não foi uma novidade introduzida em nosso sistema pela lei 11.323/05. Pode-se identificar, antes mesmo deste marco cronológico, a eficácia executiva de sentenças declaratórias em todas aquelas situações em que há o reconhecimento da existência de uma obrigação ou sua exigibilidade. São exemplos: a) a revogação da tutela antecipada já efetivada pelo autor, obrigando-o a indenizar os danos daí advindos; b) a sentença que, na ação consignatória, estabelece o montante da insuficiência do depósito (art. 899, $\mathbb{S} 2^{\circ}, \mathrm{CPC} / 1973$ e art. 545, $\mathbb{S} 2^{\circ}, \mathrm{CPC} / 2015$ ); c) a sentença que apura o saldo credor na ação de prestação de contas ( art. 918, CPC/1973 e art. 552, CPC/2019); d) o reconhecimento de uma dívida na pendência do termo

23 ZAVASCKI, 2003a , p. 226

24 “(...) 1. No atual estágio do sistema do processo civil brasileiro não há como insistir no dogma de que as sentenças declaratórias jamais têm eficácia executiva. $\mathrm{O}$ art. $4^{\circ}$, parágrafo único, do CPC considera "admissível a ação declaratória ainda que tenha ocorrido a violação do direito", modificando, assim, o padrão clássico da tutela puramente declaratória, que a tinha como tipicamente preventiva. Atualmente, portanto, o Código dá ensejo a que a sentença declaratória possa fazer juízo completo a respeito da existência e do modo de ser da relação jurídica concreta. 2 . Tem eficácia executiva a sentença declaratória que traz definição integral da norma jurídica individualizada. Não há razão alguma, lógica ou jurídica, para submetê-la, antes da execução, a um segundo juízo de certificação, até porque a nova sentença não poderia chegar a resultado diferente do da anterior, sob pena de comprometimento da garantia da coisa julgada, assegurada constitucionalmente. $\mathrm{E}$ instaurar um processo de cognição sem oferecer às partes $\mathrm{e}$ ao juiz outra alternativa de resultado que não um, já prefixado, representaria atividade meramente burocrática e desnecessária, que poderia receber qualquer outro qualificativo, menos o de jurisdicional. 3. A sentença declaratória que, para fins de compensação tributária, certifica o direito de crédito do contribuinte que recolheu indevidamente o tributo, contém juízo de certeza e de definição exaustiva a respeito de todos os elementos da relação jurídica questionada e, como tal, é título executivo para a ação visando à satisfação, em dinheiro, do valor devido. 4. Recurso especial a que se nega provimento. (REsp 588.202/PR, Rel. Ministro Teori Albino Zavascki, $1^{a}$ T., DJ 25/02/2004, p. 123) 
de vencimento sentença (art. 572, CPC/1973 - art. 514, CPC/2015)25; e, e) a sentença que decide uma relação jurídica subordinada a uma condição suspensiva (art. 572, CPC/1973 - art. 514, CPC/2015) ${ }^{26}$.

A disposição trazida pela Lei $n^{\circ} 11.232$, em 2005, no entanto, ampliou a possibilidade de eficácia executiva das sentenças declaratórias. A lei deixou claro que se o título executivo, qualquer que seja ele (decisões proferidas no processo civil que reconheçam a exigibilidade de obrigação de pagar quantia, de fazer, de não fazer ou de entregar coisa), preenche todos os requisitos necessários à atividade executiva, exigir que as partes se submetam a um novo processo de conhecimento seria violar as normas constitucionais, impedindo o acesso à justiça e violando os princípios da economia processual, conforme disse Lucon:

Se a sentença meramente declaratória contiver todos os elementos identificadores da obrigação (sujeitos, prestação, liquidez e exigibilidade) não há como se negar sua eficácia executiva. Impor uma nova cognição para que sentença futura imponha apenas a sanção executiva atenta contra o bom senso e a economia processual. ${ }^{27}$.

Inegável que a doutrina ${ }^{28}$ e a jurisprudência do STJ $^{29}$ desde a edição do art. 475-N, do CPC, introduzido pela Lei $11.232 / 05$, passaram a reconhecer a eficácia executiva das sentenças declaratórias quando certificam integralmente a existência da obrigação, porquanto há um exaurimento da atividade cognitiva “cuja repetição seria desnecessária por absoluta inutilidade, uma vez que o único

25 A sentença que está sujeita a um termo inicial é uma sentença inexigível, pois o direito subjetivo existe antes do nascimento do termo, onde o que se pleiteia é a eliminação da incerteza acerca da existência ou conteúdo relação jurídica, com intuito preventivo, função típica das ações declaratórias, e não a imposição de uma sanção (ZAVASKI, 2003a, pp. 227-229)

26 O art. 514 do CPC de 2015 estabelece que "quando o juiz decidir relação jurídica sujeita a condição ou termo, o cumprimento da sentença dependerá de demonstração de que se realizou a condição ou de que ocorreu o termo “. Expressão simular trazia o art. 572, CPC/1973, "quando o juiz decidir relação jurídica sujeita a condição ou termo, o credor não poderá executar a sentença sem provar que realizou a condição ou que ocorreu o termo". A doutrina sempre entendeu, sob a égide do CPC de 1973, que não se trata de ação condenatória, mas de ação declaratória em que se decide acerca da existência de uma relação jurídica sujeita a termo ou condição, sendo a decisão tomada um título executivo desde que acompanhada da prova que se realizou a condição ou ocorreu o termo. Afirmava trata-se de título executivos complexo ou misto que são formados da sentença de natureza declaratória, que decidiu a respeito da existência ou do conteúdo da relação jurídica, sendo acompanhada de documento comprobatório da realização da condição ou de documento que comprove a ciência do fato pelo devedor. (ZAVASKI, 2003a, pp. 227-229)

27 LUCON, 2005, p. 152.

28 KNIJNIK, 2006, p. 159; MATTOS, 2006, p. 172; CARNEIRO, 2007, p. 86; MOUZALAS, 2014b, p. 121-165; THEODORO JÚNIOR, 2017, p. 30; DIDIER JR., CUNHA, BRAGA, OLIVEIRA: 2017, p. 266.

29 “(...) a sentença declaratória que, para fins de compensação tributária, certifica o direito de crédito do contribuinte que recolheu indevidamente o tributo, contém juízo de certeza e de definição exaustiva a respeito de todos os elementos da relação jurídica questionada e, como tal, é título executivo para a ação visando à satisfação, em dinheiro, do valor devido. (...) (AgRg nos EDcl no REsp 1031800/SC, Rel. Ministro Mauro Campbell Marques, 2a T., DJe 23/04/2009). 
resultado seria reafirmar o que foi proclamado pelo provimento anterior" ${ }^{30}$. Logo, negar executividade a um título executivo onde estão definidos os sujeitos ativo e passivo, a prestação, a exigibilidade, enfim, todos os requisitos exigidos pela lei para desencadear os atos executivos é ferir o direito constitucional à tutela executiva.

Há uma assimilação dos efeitos da sentença declaratória e condenatória, em todos os casos em que, na sentença declaratória, a atividade cognitiva esteja completa sem que remanesça resíduo algum a ensejar nova ação de conhecimento, conforme se extrai do primeiro paradigma do STJ a reconhecer a exigibilidade em tais situações:

(...) 1. No atual estágio do sistema do processo civil brasileiro não há como insistir no dogma de que as sentenças declaratórias jamais têm eficácia executiva. $\mathrm{O}$ art. $4^{\circ}$, parágrafo único, do $\mathrm{CPC}$ considera "admissível a ação declaratória ainda que tenha ocorrido a violação do direito", modificando, assim, o padrão clássico da tutela puramente declaratória, que a tinha como tipicamente preventiva.

Atualmente, portanto, o Código dá ensejo a que a sentença declaratória possa fazer juízo completo a respeito da existência e do modo de ser da relação jurídica concreta.

2. Tem eficácia executiva a sentença declaratória que traz definição integral da norma jurídica individualizada. Não há razão alguma, lógica ou jurídica, para submetê-la, antes da execução, a um segundo juízo de certificação, até porque a nova sentença não poderia chegar a resultado diferente do da anterior, sob pena de comprometimento da garantia da coisa julgada, assegurada constitucionalmente. $\mathrm{E}$ instaurar um processo de cognição sem oferecer às partes e ao juiz outra alternativa de resultado que não um, já prefixado, representaria atividade meramente burocrática e desnecessária, que poderia receber qualquer outro qualificativo, menos o de jurisdicional.

3. A sentença declaratória que, para fins de compensação tributária, certifica o direito de crédito do contribuinte que recolheu indevidamente o tributo, contém juízo de certeza e de definição exaustiva a respeito de todos os elementos da relação jurídica questionada e, como tal, é título executivo para a ação visando à satisfação, em dinheiro, do valor devido. (...) ${ }^{31}$.

Tratava-se, na espécie, das sentenças que declaravam o direito à compensação de créditos tributários ou à revisão de benefícios previdenciários. $\mathrm{O}$ entendimento fixado foi o de que, havendo a definição dos sujeitos da relação jurídica e a existência de juízo de certeza a respeito de todos os elementos da norma jurídica individualizada, garantida estaria a eficácia executiva da decisão declaratória. Decidiu o STJ que, em tais casos, não haveria mais necessidade que o beneficiário ajuizasse demanda condenatória para perceber os valores a que tinha direito: ação de repetição de indébito, na primeira hipótese, ou execução das parcelas retroativas dos benefícios pagos a menor, na segunda.

30 ZAVASCK, 2003b, p. 55.

31 EREsp 609.266/RS, Rel. Ministro Teori Albino Zavascki, 1ª Seção, DJ 11/09/2006. 
As decisões do STJ que se seguiram redundaram na edição da súmula 461, do STJ 32: “O contribuinte pode optar por receber, por meio de precatório ou por compensação, o indébito certificado por sentença declaratória transitada em julgado", até que, em 2011, deu-se o julgamento do REsp 1.261.888/RS, segundo o rito previsto no art. 543-C do CPC - tema repetitivo 509:

PROCESSUAL CIVIL. RECURSO ESPECIAL REPRESENTATIVO DE CONTROVÉRSIA. ART. 543-C DO CPC. SENTENÇA QUE CONDENA CONCESSIONÁRIA DE ENERGIA ELÉTRICA EM OBRIGAÇÃO DE NÃO FAZER (IMPEDIMENTO DE CORTE NO FORNECIMENTO) E DECLARA LEGAL A COBRANÇA IMPUGNADA EM JUÍZO, SALVO QUANTO AO CUSTO ADMINISTRATIVO DE 30\% REFERENTE A CÁLCULO DE RECUPERAÇÃO. APLICAÇÃO DO ART. 475-N, INC. I, DO CPC PELA CONCESSIONÁRIA EM RELAÇÃO À PARTE DO QUE FOI IMPUGNADO PELO CONSUMIDOR NA FASE DE CONHECIMENTO. POSSIBILIDADE NO CASO CONCRETO.

1. Com a atual redação do art. 475-N, inc. I, do CPC, atribuiu-se "eficácia executiva" às sentenças "que reconhecem a existência de obrigação de pagar quantia”.

2. No caso concreto, a sentença que se pretende executar está incluída nessa espécie de provimento judicial, uma vez que julgou parcialmente procedente o pedido autoral para (i) reconhecer a legalidade do débito impugnado, embora (ii) declarando inexigível a cobrança de custo administrativo de $30 \%$ do cálculo de recuperação de consumo elaborado pela concessionária recorrente, e (iii) discriminar os ônus da sucumbência (v. fl. 26, e-STJ).

3. Recurso especial provido. Acórdão submetido ao regime do art. 543-C do CPC e da Resolução STJ n. 8/0833.

Conforme decisão supra, ficou assentada a executividade das sentenças que reconhecem a existência de obrigação de pagar quantia. Na espécie, o STJ condenou a concessionária de energia elétrica em obrigação de não fazer (impedimento de corte no fornecimento) e declarou legal a cobrança impugnada em juízo, reconhecendo a possibilidade da concessionária de energia promover o cumprimento de sentença declaratória de débito nos próprios autos, consagrando o entendimento de que nas ações declaratórias em que a atividade cognitiva está completa a respeito da existência de todos os elementos da norma jurídica individualizada - certeza, liquidez e exigibilidade - a fase executiva impõe-se por expressa determinação legal em reconhecimento ao princípio do acesso à justiça, assegurado constitucionalmente.

No entanto, a questão de fundo referente à exequibilidade de sentenças declaratórias quer a decisão contenha julgamento de procedência, quer de improcedência, dada a natureza dúplice do elemento declaratório, presente em toda decisão judicial, ainda prevalecia.

32 DJe 8.9.2010

33 REsp 1261888/RS, Rel. Ministro Mauro Campbell Marques, $1^{a}$ Seção, DJe 18/11/2011. 
A ação declaratória encaixa-se no conceito de ação dúplice ${ }^{34} 35$ porque a declaração de inexistência do direito afirmado pelo autor dá ao demandado tutela de igual qualidade à que concederia ao autor no caso de procedência da demanda ${ }^{36}$. Uma vez que a ação dúplice decorre da peculiaridade do direito material $^{37}$, independentemente do polo processual que ocupem, a discussão judicial propiciará o bem da vida a uma das partes ${ }^{38}$, por isso o réu não precisa formular pedido, pois a simples defesa implica no exercício da pretensão ${ }^{39}$. Logo, a improcedência do pedido do autor implicará no atendimento da pretensão do réu, obtendo este o provimento jurisdicional idêntico àquele inicialmente buscado pelo autor, Foi como já afirmou Pontes:

O 'não tem razão', nas ações declarativas, importa em 'tem razão', para a outra parte, ou para as outras partes. Tem-se de atende a que a ação declarativa tem como finalidade precípua, proponderante, o enunciado existencial: se perde quem disse que 'é', ganha quem disse que 'não é', se perde quem disse que 'não é, ganha quem disse que 'é". ${ }^{40}$

Sendo, o caráter dúplice, da essência da ação declaratória, em razão da natureza do direito material em jogo e do pedido formulado ${ }^{41}$, a doutrina ${ }^{42}$ passou a admitir que o art. 475-N, I do CPC/1973, também deveria ser aplicado às sentenças que, julgando improcedente (parcial ou totalmente) o pedido de declaração de inexistência de relação jurídica obrigacional, reconhecessem a existência da obrigação do demandante para com o demandado. Essa questão levou Teori Zavaski, a publicar, em 2012, o artigo "executividade das sentenças de improcedência nas ações declaratórias negativas”, defendendo que tais sentenças também são dotadas de eficácia executiva uma vez que certificam integralmente a existência da obrigação exaurindo da atividade executiva. Assim afirmou:

Em demandas em que busca provimento judicial para certificar a existência ou a inexistência de uma relação jurídica obrigacional, a procedência e a improcedência do pedido representam o verso e o reverso inseparáveis da mesma moeda. O julgamento de mérito importará necessariamente um juízo de certeza sobre

$34 \mathrm{O}$ instituto das ações dúplices tem origem no direito romano, cuja denominação refere-se à condição dos litigantes que ocupam as posições jurídicas ativas e passivas concomitantemente, não se podendo falar em autor e réu (DEMARCHI, 2010, p. 358)

35 São exemplos típicos de ações dúplices do direito romano, que ainda remanescem no nosso sistema processual, as ações possessórias e as ações divisórias.

36 MOUZALAS, 2014, p. 129

37 ASSIS, 1996, p. 93; DEMARCHI, 2010, p. 367.

38 DIDIER JR., 2017, p. 340.

39 DEMARCHI, 2010, pp. 358-359; MARCATO, 2008, p. 63; ASSIS, 1998, 220; DIDIER JR., 2017, p. 340; MOUZALAS, 2014, p. 118.

40 PONTES DE MIRANDA, 1976, p. 64

41 BONDIOLI, 2009, p. 55; NEVES, 2018, p. 1.111.

42 WAMBIER, WAMBIER, MEDINA, 2006, p 167; JORGE, DIDIER JR, RODRIGUES, 2006, p. 173/174; SANTOS, 2006, p. 31. 
a existência ou sobre a inexistência da obrigação, sendo que, em qualquer dos casos, a sentença terá eficácia preceitual para as partes, como verdadeira norma individualizada ("lei entre as partes") e, transitando em julgado, será imutável e indiscutível. Quando improcedente, conferirá, portanto, tutela jurisdicional em favor do demandado, independentemente de reconvenção. Aliás, em alguns casos, a norma processual deixa expresso esse potencial efeito dúplice, sendo exemplos inequívocos as sentenças de mérito em ações possessórias (CPC, art. $920)$, em ações de consignação em pagamento (CPC, art. $899, \mathbb{\$} 2^{\circ}$ ) e em ações de prestação de contas (CPC, art.918) ${ }^{43}$.

A duplicidade das ações declaratórias pode ocorrer tanto nos casos de ação declaratória positiva - pede-se a declaração de existência de um determinado direito, quanto nos casos de ação declaratória negativa - postula-se o reconhecimento da inexistência de um direito ${ }^{44}$, o que levou ao entendimento de que, ao julgar improcedente o pedido de declaração de inexistência da relação jurídica obrigacional, a sentença exaure inteiramente a atividade de certificação da existência da obrigação, permitindo o cumprimento da sentença, conforme se extrai do voto proferido no julgamento do REsp n. 1.300.213/RS ${ }^{45}$ :

43 ZAVASKI, 2012, p. 19.

44 BONDIOLI. 2006, p. 5.

45 “(...) 1. Nos termos do art. 475-N, I do CPC, é título executivo judicial 'a sentença proferida no processo civil que reconheça a existência da obrigação de fazer, não fazer, entregar coisa ou pagar quantia'. Antes mesmo do advento desse preceito normativo, a uníssona jurisprudência do STJ, inclusive em julgamento de recurso representativo de controvérsia (REsp 1.114.404, $1^{a}$ Seção, Min. Mauro Campbell Marques, DJ de 01.03.10), já atestara a eficácia executiva da sentença que traz definição integral da norma jurídica individualizada. Não há razão alguma, lógica ou jurídica, para submeter tal sentença, antes da sua execução, a um segundo juízo de certificação cujo resultado seria necessariamente o mesmo, sob pena de ofensa à coisa julgada. 2. Nessa linha de entendimento, o art. 475-N, I do CPC se aplica também à sentença que, julgando improcedente (parcial ou totalmente) o pedido de declaração de inexistência de relação jurídica obrigacional, reconhece a existência de obrigação do demandante para com o demandado. Essa sentença, como toda a sentença de mérito, tem eficácia de lei entre as partes (CPC, art. 468) e, transitada em julgado, torna-se imutável e indiscutível (CPC, art. 467), ficando a matéria decidida acobertada por preclusão, nesse ou em qualquer outro processo (CPC, art. 471), salvo em ação rescisória, se for o caso. (...)” (REsp n. 1.300.213/RS, relator Ministro Teori Albino Zavascki, $1^{a}$ T., DJe de 18/4/2012.)

No mesmo sentido: “ (...) 2. As sentenças que, mesmo não qualificadas como condenatórias, ao declararem um direito, atestem, de forma exauriente, a existência de obrigação certa, líquida e exigível, são dotadas de força executiva, constituindo-se título executivo judicial, nos termos do art. 475- N, I, do CPC, introduzido pela Lei n. 11. 232/2005. 3. Referido dispositivo processual aplica-se também às sentenças declaratórias que, julgando improcedente o pedido do demandante, reconhecem a existência de obrigação do autor em relação ao réu da demanda, independentemente de constar na contestação pedido de satisfação de crédito, legitimando o réu a propor o cumprimento de sentença. 4. In casu, a sentença de improcedência proferida nos autos da ação de anulação de notas promissórias emitidas em favor do demandado, em garantia de dívidas decorrentes de empréstimos contraídos pelo autor, declarou susbsistente a obrigação cambial entre as partes, resguardando apenas o abatimento do valor reconhecidamente pago pelo demandante. Consectariamente, reconhecida a certeza, a exigibilidade e a liquidez da obrigação cambial, deve-se dar prosseguimento ao pedido de cumprimento de sentença formulado pelo demandado, ante a aplicação do disposto no art. 475-N, I, do CPC à espécie. (...)” (REsp n. 1.481.117/PR, relator Ministro João Otávio de Noronha, $3^{\mathrm{a}}$ T., DJe de 10/3/2015.); “ 
Essa linha de fundamentação é inteiramente aplicável às hipóteses como a dos autos: ao julgar improcedente o pedido de declaração de inexistência da relação jurídica obrigacional, a sentença acabou exaurindo inteiramente a atividade de certificação da existência da obrigação, inclusive no que se refere aos sujeitos e à natureza da relação jurídica, bem como ao valor e à exigibilidade da prestação. Nada mais resta a certificar. Ora, essa sentença, como toda a sentença de mérito, tem eficácia de lei entre as partes (CPC, art. 468) e, transitada em julgado, torna-se imutável e indiscutível (CPC, art. 467), ficando a matéria decidida acobertada por preclusão, nesse ou em qualquer outro processo (CPC, art. 471), salvo em ação rescisória, se for o caso. É descabido o raciocínio - que às vezes comanda, ao menos implicitamente, certas afirmações em doutrina e jurisprudência -, de que somente as sentenças de procedência têm a força de preceito e podem se revestir da imutabilidade da coisa julgada. Também as de improcedência têm tais propriedades, e as têm em idêntico grau de intensidade. Elas também são, como é notório, sentenças de acertamento. (...) (grifos nossos)

Assim como as sentenças de procedência, as de improcedência têm as mesmas propriedades - a força de preceito e a autoridade da coisa julgada-, e com a mesma intensidade porque também são sentenças de acertamento.

O potencial efeito dúplice das ações declaratórias torna desnecessário o pedido reconvencional, pois, sendo a pretensão da reconvenção diferente da que é exercida na ação contra o réu ${ }^{46}$, visto que fundada em relação jurídica de direito material distinta, embora conexa com a da ação principal, com ela não se confunde, não havendo interesse processual em reconvir ${ }^{47}$. Logo, prevaleceu a noção de que a sentença declaratória, ao analisar o mérito, julga a causa inteiramente e, sendo de improcedência, dá ao demandado a tutela jurídica de que necessita, com o mesmo efeito prático da reconvenção.

O STJ acompanhou tal entendimento em vários julgados, firmando o posicionamento de que as sentenças, mesmo quando não qualificadas como condenatórias, são dotadas de força executiva, se, ao declararem um direito, atestam, de forma exauriente, a existência de obrigação certa, líquida e exigível $^{48}$. Configurando-se falta de interesse de agir, o ajuizamento de nova ação de

(...). 'O art. 475-N, I do CPC se aplica também à sentença que, julgando improcedente (parcial ou totalmente) o pedido de declaração de inexistência de relação jurídica obrigacional, reconhece a existência de obrigação do demandante para com o demandado. Essa sentença, como toda a sentença de mérito, tem eficácia de lei entre as partes (CPC, art. 468) e, transitada em julgado, torna-se imutável e indiscutível (CPC, art. 467), ficando a matéria decidida acobertada por preclusão, nesse ou em qualquer outro processo (CPC, art. 471), salvo em ação rescisória, se for o caso' (...).” (AgRg no AREsp n. 385.551/RJ, relator Ministro Arnaldo Esteves Lima, $1^{\text {a }}$ T., DJe de 11/2/2014.)

46 MIRANDA, Pontes de. Comentários ao Código de Processo Civil, Tomo V, RJ: Forense, 1974, p.161

47 MOREIRA, José Carlos Barbosa. O novo processo civil brasileiro, $27^{\mathrm{a}}$ ed., RJ: Forense, 2008, p. 45

48 “(...) 1. A Lei 11.232/2005, ao revogar o art. 584 e inserir o art. 475-N no Código de Processo Civil, acolheu o entendimento já esposado por esta Corte de que as sentenças de cunho declaratório podem ter força executiva se presentes os elementos necessários à execução, como 
conhecimento para obter a liquidação judicial ${ }^{49}$, uma vez que o espírito da norma é prestigiar os princípios da efetividade e da celeridade ${ }^{50}$.

Nessa linha, afirmou aquela Corte que a sentença declaratória em ação de revisão de contrato pode ser executada pelo réu mesmo sem ter havido reconvenção, tendo em vista a presença de elementos suficientes com caráter de duplicidade dessas ações e o princípio da economia ${ }^{51}$, aplicando-se também às sentenças declaratórias que, julgando improcedente, parcial ou totalmente, o pedido do demandante, reconhecem a existência de obrigação do autor em re-

exigibilidade e certeza da relação. Precedentes. 2. Caso concreto em que a declaração de um valor menor a título de honorários já implica, por decorrência lógica, que a diferença a maior é indevida. (...)"(AgRg no REsp 1384913/ES, Rel. Ministro Paulo De Tarso Sanseverino, $3^{\mathrm{a}} \mathrm{T}$., DJe 24/08/2015); “(...)1. Para que uma sentença declaratória se constitua no título executivo judicial previsto no art. 475-N, I, do CPC, é necessário que ateste, de forma exauriente e com força de coisa julgada, a existência de obrigação certa, líquida e exigível. 2. Esse juízo de certeza sobre a relação de direito material geradora da obrigação de pagar, dar ou fazer deve constar da parte dispositiva da sentença, compreendida em seu sentido substancial, que é acobertada pelo instituto da coisa julgada e, portanto, apta a se constituir em título executivo judicial. 3. Recurso especial conhecido e desprovido. (REsp 1508910/SP, Rel. Ministro João Otávio De Noronha, $3^{\mathrm{a}}$ T.,DJe 26/05/2015)”; “ (...) 3. Segundo jurisprudência sedimentada nesta Corte, confere-se eficácia executiva lato sensu ao provimento declaratório que acerta a relação jurídica discutida na demanda, pois 'Não há razão alguma, lógica ou jurídica, para submeter tal sentença, antes da sua execução, a um segundo juízo de certificação, cujo resultado seria necessariamente o mesmo, sob pena de ofensa à coisa julgada' (...)” (REsp n. 1.336.089/RJ, relatora Ministra Eliana Calmon, 2 ${ }^{\text {a }}$ T, DJe de 17/10/2012);

49 “ (...) “Tem eficácia executiva a sentença declaratória que traz definição integral da norma jurídica individualizada. Não há razão alguma, lógica ou jurídica, para submetê-la, antes da execução, a um segundo juízo de certificação, até porque a nova sentença não poderia chegar a resultado diferente do da anterior, sob pena de comprometimento da garantia da coisa julgada, assegurada constitucionalmente. E instaurar um processo de cognição sem oferecer às partes e ao juiz outra alternativa de resultado que não um, já prefixado, representaria atividade meramente burocrática e desnecessária, que poderia receber qualquer outro qualificativo, menos o de jurisdicional.” (...) 5. Tendo o recorrente sentença declaratória já transitada em julgado, o ajuizamento de nova ação de conhecimento para obter a liquidação judicial pretendida configura falta de interesse de agir." (...) (grifos nossos) (AgRg nos EDcl no REsp 1462896/RS, Rel. Ministro Mauro Campbell Marques, $2^{\text {a }}$ T,DJe 22/10/2015)

50 “(...). 1. A inovação trazida pelo art. 475-N, I, do CPC, introduzida pela Lei n. 11.232/2005, conferiu eficácia executiva à sentença proferida no processo civil que reconheça a existência de obrigação de fazer, não fazer, entregar coisa ou pagar quantia. (...) 2. O espírito da norma em comento é prestigiar os princípios da efetividade e da celeridade, porquanto não se revela razoável impor ao demandante o ônus de propor nova ação de conhecimento, agora condenatória, quando já existente decisão judicial que contenha juízo de certeza e de definição acerca do direito do autor. 3. Assim, existindo juízo inequívoco quanto ao direito a parcelas atrasadas, há de se admitir a eficácia executiva da sentença declaratória, mesmo não havendo determinação expressa na decisão judicial. (...) (grifos nossos) (REsp 1422401/PR, Rel. Ministro Sérgio Kukina, $1^{\text {a }}$ T., DJe 30/05/2014)

51 “(...) 1.- As sentenças de cunho declaratório podem ter força executiva, se presentes os elementos necessários à execução, como exigibilidade e certeza da relação. Precedentes. 2.- A sentença declaratória em ação de revisão de contrato pode ser executada pelo réu, mesmo sem ter havido reconvenção, tendo em vista a presença dos elementos suficientes à execução, o caráter de "duplicidade" dessas ações, e os princípios da economia, da efetividade e da duração razoável do processo (....)." (grifos nossos) (AgRg no REsp n. 1.446.433/SC, relator Ministro Sidnei Beneti, $3^{\mathrm{a}}$ T., DJe de 9/6/2014). 
lação ao réu da demanda, independentemente de constar na contestação pedido de satisfação de crédito $^{52}$. Do mesmo modo tem eficácia executiva as demandas desconstitutivas, onde se questiona a anulação da penalidade aplicada, visando a desconstituição da sanção e devolução dos valores pagos a título de multa ${ }^{53}$.

Também admitiu, o STJ, nos casos de obrigação fiscal, que a sentença de mérito proferida na ação anulatória de remissão de débitos de ICMS constitui título executivo suficiente para ensejar a atividade de execução forçada, sendo providência inútil submeter o prosseguimento da atividade executiva judicial à formalidade administrativa de novo lançamento tributário, nos termos do art. 142 do Código Tributário Nacional ${ }^{54}$.

52 “(...) 1. As sentenças que, mesmo não qualificadas como condenatórias, ao declararem um direito, atestem, de forma exauriente, a existência de obrigação certa, líquida e exigível são dotadas de força executiva, constituindo título executivo judicial, nos termos do art. 475-N, I, do CPC, introduzido pela Lei n. 11.232/2005. 2. Referido artigo processual aplica-se também às sentenças declaratórias que, julgando improcedente, parcial ou totalmente, o pedido do demandante, reconhecem a existência de obrigação do autor em relação ao réu da demanda, independentemente de constar na contestação pedido de satisfação de crédito, legitimando o réu a propor o cumprimento de sentença. 3. A ratio desse entendimento está na ausência de necessidade lógica ou jurídica de se submeter a sentença que já tenha feito um juízo completo a respeito da relação jurídica concreta a uma nova certificação antes de ser executada. Isso porque a nova sentença nem sequer poderia chegar a resultado diferente do anterior, sob pena de violação da coisa julgada. 4. In casu, a sentença de parcial improcedência proferida nos autos da ação revisional de contrato de mútuo habitacional, transitada em julgado e objeto de liquidação proposta pela instituição financeira, que apresentou memória de cálculos do valor do quantum debeatur, definiu todos os critérios a serem observados para a satisfação do crédito da instituição financeira. Consectariamente, reconhecida a certeza, a exigibilidade e a liquidez da obrigação contratual, deve-se dar prosseguimento ao pedido de cumprimento de sentença formulado pelo demandado, ante a aplicação do disposto no art. 475-N, I, do CPC à espécie.

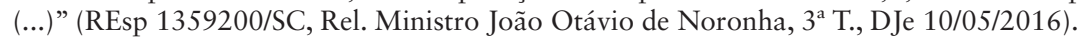

53 "PROCESSUAL CIVIL. MULTAS DE TRÂNSITO. AÇÃO DESCONSTITUTIVA. RECUPERAÇÃO DOS VALORES PAGOS A TÍTULO DE MULTA. TÍTULO EXECUTIVO E COISA JULGADA. EXECUÇÃO POR QUANTIA CERTA DE SENTENÇA EMINENTEMENTE DESCONSTITUTIVA. 1. Hipótese em que a decisão monocrática deu provimento ao Recurso Especial a fim de reformar o acórdão, que consignou: "considerando que a parte agravante, em sua ação de conhecimento, não postulou a devolução de qualquer valor, mas apenas a anulação da penalidade aplicada, não pode vir em sede de liquidação de sentença, invocar questão que não foi objeto de pedido". 2. A demanda ajuizada questiona a sanção como um todo e busca sua desconstituição. Sem adentrar vetustos debates sobre cargas de eficácia de decisões, a desconstituição da multa aplicada pressupõe a declaração de sua insubsistência por violação do devido processo legal. A alteração concreta produzida pela eficácia constitutiva negativa não esgota os efeitos do repúdio à sanção aplicada. O iter de rejeição à imposição estatal termina com a recuperação dos valores, corolário inquestionável da declaração de inexistência da multa, ainda que por motivos formais. 3. Decorrência disso é a alteração do CPC, que previu como título executivo não mais a sentença exclusivamente condenatória, e sim aquela que "reconheça a existência de obrigação de fazer, não fazer, entregar coisa ou pagar quantia" (art. 475-N, I, do CPC), possibilitando a execução de sentenças formalmente declaratórias. Nessas situações, "não há razão alguma, lógica ou jurídica, para submeter tal sentença, antes da sua execução, a um segundo juízo de certificação, cujo resultado seria necessariamente o mesmo, sob pena de ofensa à coisa julgada" (...)". (AgRg no REsp 1018250/RS, Rel. Ministro Herman Benjamin, 2a T., DJe 25/09/2014)";

54 “(...) 5 . Tendo as partes provocado o Poder Judiciário para a solução da controvérsia a respei-

Rev. Fac. Direito UFMG, Belo Horizonte, n. 75, pp. 487-512, jul./dez. 2019 
Enfim, em vários julgados o STJ passou a admitir que a sentença proferida no processo civil que reconheça a existência da obrigação de fazer, não fazer, entregar coisa ou pagar quantia, se aplica também às chamadas sentenças declaratórias positivas que julgam improcedente (parcial ou totalmente) o pedido de declaração de inexistência de relação jurídica obrigacional, porque, ao assim fazê-lo, reconhecem a existência da obrigação do demandante para com o demandado.

Em tais decisões foi fixado o entendimento de que a eficácia executiva ocorre quando presentes os elementos necessários à execução, como exigibilidade e certeza da relação, sendo denegada a executividade nos casos em que não haja o reconhecimento da obrigação (em hipóteses em a sentença declaratória julga improcedente tão-somente o pedido declaratório de inexistência de obrigação $)^{55}$, até que em 2016, houve o julgamento do REsp 1.324.152/SP, segundo o rito dos processos repetitivos (tema 899), cujo acórdão restou assim ementado:

PROCESSO CIVIL. RECURSO ESPECIAL REPRESENTATIVO DA CONTROVÉRSIA. ART. 543-C DO CPC. EXEQUIBILIDADE DE SENTENÇAS NÃO CONDENATÓRIAS. ARTIGO 475-N, I, DO CPC.

1. Para fins do art. 543-C do CPC, firma-se a seguinte tese: "A sentença, qualquer que seja sua natureza, de procedência ou improcedência do pedido, constitui título executivo judicial, desde que estabeleça obrigação de pagar quantia, de fazer, não fazer ou entregar coisa, admitida sua prévia liquidação e execução nos próprios autos". 2. No caso, não obstante tenha sido reconhecida a relação obrigacional entre as partes, decorrente do contrato de arrendamento mercantil, ainda é controvertida a existência ou não de saldo devedor - ante o depósito de várias somas no decorrer do processo pelo executado - e, em caso positivo, qual o seu montante atualizado. Sendo perfeitamente possível a liquidação da dívida previamente à fase executiva do julgado, tal qual se dá com as decisões condenatórias carecedoras de liquidez, deve prosseguir a execução, sendo certa a possibilidade de sua extinção se verificada a plena quitação do débito exequendo. 3. Recurso especial provido ${ }^{56}$.

to da obrigação fiscal, a sentença de mérito proferida na ação anulatória de remissão de débitos de ICMS (que tem natureza de ação cognitiva) produziu juízo sobre a sua existência e o seu conteúdo. Constituiu-se, portanto, título executivo suficiente para ensejar a atividade de execução forçada (...). Nesse contexto, mostra-se providência inútil submeter o prosseguimento da atividade executiva judicial à formalidade administrativa de novo lançamento tributário, nos termos do art. 142 do Código Tributário Nacional, ato com função meramente declaratória que não poderia, de modo algum, desbordar do que ficou reconhecido no âmbito jurisdicional. (...) (AgRg no REsp 1460032/RN, Rel. Ministro Humberto Martins, 2a T., DJe 14/09/2015)

55 “(...) 1. Trata-se de ação declaratória em que se buscou a nulidade de débito proveniente de recuperação de consumo de tarifa de energia elétrica, a qual foi julgada improcedente, sendo o autor condenado ao pagamento das verbas de sucumbência. 2. Assim, somente caberia o pedido de execução em relação às referidas verbas de sucumbência e nada mais. Com efeito, não houve o reconhecimento de existência de obrigação de fazer, não fazer, entregar coisa ou pagar quantia, conforme preceitua o art. 475-N do CPC (...)" (AgRg no AREsp 720.870/SP,

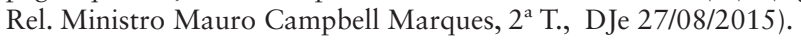

56 REsp 1324152/SP, Rel. Ministro Luis Felipe Salomão, Corte Especial, DJe 15/06/2016 
A questão, contudo, não está resolvida, uma vez que não se pode afirmar que todas as sentenças de improcedência de demanda declaratória de inexistência de obrigação podem ser consideradas título executivo judicial.

Observe-se que, na decisão, o STJ ao afirmar a executoriedade das sentenças de improcedência lastreou o seu entendimento na duplicidade das ações declaratórias, admitindo que a declaração de inexistência do direito afirmado pelo autor dá ao demandado tutela de igual qualidade à que concederia ao autor no caso de procedência da demanda, sem levar em consideração que tal ocorre somente à luz daquela causa de pedir.

A decisão firmou seu entendimento no reconhecimento de que o que vai determinar a eficácia executiva é se a situação jurídica do titular do direito tenha sido completa e previamente reconhecida em título executivo.

Aliás, o CPC de 2015 ao trazer no artigo 515, I, que "são títulos executivos judiciais "as decisões proferidas no processo civil que reconheçam a exigibilidade de obrigação de pagar quantia, de fazer, de não fazer ou de entregar coisa”, corroborou o entendimento já fixado no CPC de 1973, admitindo que a sentença declaratória não é mais meramente declaratória, mas tem a mesma eficácia executiva da sentença condenatória, pois passou a ser título executivo por expressa determinação legal, desde que estejam presentes todos os elementos identificadores da obrigação. Cita-se as palavras de Theodoro Júnior:

Observe-se, porém, que nem toda sentença meramente declaratória pode valer como título executivo, mas apenas aquela que na forma do art. $4^{\circ}$, parágrafo único, do CPC/1973 (NCPC, art. 20), se refira à existência de relação obrigacional já violada pelo devedor. Ou seja, a que reconheça "a exigibilidade de obrigação de pagar quantia, de fazer, de não fazer ou de entregar coisa" (NCPC, art. 515, I). As que se limitam a conferir certeza à relação de que não conste dever de realizar modalidade alguma de prestação (como, v.g., a nulidade de negócio jurídico ou a inexistência de dívida ou obrigação) não terão, obviamente, como desempenhar o papel de título executivo, já que nenhuma prestação terá a parte a exigir do vencido ${ }^{57}$.

Nesse sentido, no voto do referido julgamento (REsp 1.324.152/SP -tema 899), o relator afirmou que os dispositivos legais (art. 475-N do CPC/1973, introduzido pela Lei n. 11.282/2005, e art. 515, I, CPC 2015) não atribuem eficácia executiva a todas as sentenças declaratórias indiscriminadamente, mas apenas àquelas que, reconhecendo a existência da obrigação, contenham, em seu bojo, os pressupostos de certeza e exigibilidade:

"Nesse ponto, é relevante salientar que os referidos dispositivos legais não atribuem eficácia executiva a todas as sentenças declaratórias indiscriminadamente, mas apenas àquelas que, reconhecendo a existência da obrigação, contenham, em seu bojo, os pressupostos de certeza e exigibilidade (art. 586 do CPC), sendo certo que, na ausência de liquidez, é admitida a prévia liquidação, tal qual ocorre com o provimento condenatório".

57 THEODORO JÚNIOR, 2017, p. 32 
E encaminhou o seguinte entendimento a ser firmado:

A sentença, qualquer que seja sua natureza, seja de procedência ou improcedência do pedido, constitui título executivo judicial, desde que estabeleça obrigação de pagar quantia, de fazer, não fazer ou entregar coisa, admitida sua prévia liquidação e execução nos próprios autos.

Contudo, não se pode afirmar que toda a sentença de improcedência de demanda declaratória pode ser considerada título executivo judicial. Em se tratando de sentença de improcedência de demanda declaratória de inexistência de obrigação, a eficácia executiva não será determinada apenas pelo reconhecimento de todos os elementos identificadores da obrigação, mas será necessário analisar se, à luz daquela causa de pedir, a duplicidade da ação declaratória no tocante à inexistência do direito afirmado pelo autor dá ao demandado tutela de igual qualidade à que concederia ao autor no caso de procedência da demanda.

Em suma, o entendimento firmado pelo STJ no voto do REsp 1.324.152/SP (Tema 899), de que a sentença qualquer que seja sua natureza, seja de procedência ou improcedência do pedido, constitui título executivo judicial, desde presentes todos os elementos identificadores da obrigação, deve ser melhor analisado, uma vez que não se pode afirmar que todas sentenças de improcedência de demanda declaratória de inexistência de obrigação podem ser consideradas título executivo judicial, conforme explicar-se-á no próximo tópico.

\section{REFLEXÕES ACERCA DA SENTENÇA DE IMPROCEDÊNCIA DE DEMANDA DECLARATÓRIA DE INEXISTÊNCIA DE OBRIGA- ÇÃO}

O art. 515, I, do CPC, ao reconhecer como título executivo todas “as decisões proferidas no processo civil que reconheçam a exigibilidade de obrigação de pagar quantia, de fazer, de não fazer ou de entregar coisa”, acolheu entendimento que já vinha se consolidando no regime do Código anterior, segundo o qual a sentença meramente declaratória é título executivo judicial desde que reconheça a exigibilidade de uma obrigação ${ }^{58}$. É lição de Teori:

É equívoco, portanto, afirmar que a sentença condenatória, ou outra sentença qualquer, é constitutiva da sanção ou do estado de sujeição aos atos de execução forçada. Não é esta, consequentemente, a justificação para a força executiva dessa espécie de sentença. Sua executividade decorre, isto sim, da circunstância de se tratar de sentença que traz identificação completa de uma norma jurídica individualizada, que, por sua vez, tem em si, conforme se viu, a força de autorizar a pretensão à tutela jurisdicional. Se há 'identificação completa' da norma individualizada é porque a fase cognitiva está integralmente atendida, de modo que a tutela jurisdicional autorizada para a situação é a executiva.

58 SANTOS, 2017, p. 30; NUNES, 2018, p. 1.112, THEODORO JÚNIOR, 2017, p. 32; WAMBIER, CONCEIÇÃO, RIBEIRO, MELLO, 2016, p. 933-934 
Em outras palavras: se já está judicialmente reconhecido que a obrigação existe e está vencida, o dever da entrega da correspondente prestação é decorrência natural e necessária, prescindindo de nova intermediação judicial para que isso ocorra. Não fosse assim, não haveria como justificar a força executiva dos títulos extrajudiciais ${ }^{59}$.

A doutrina e a jurisprudência ${ }^{60}$ tem assimilado a compreensão de exigibilidade das sentenças declaratórias de uma forma bastante elástica admitindo que, em razão do seu caráter dúplice, toda sentença de improcedência de demanda declaratória de inexistência de obrigação é um título executivo judicial ${ }^{61}$.

Não nos parece assim. Não se pode afirmar que toda sentença de improcedência de demanda declaratória de inexistência de obrigação seja um título executivo judicial, porque o que permite a exequibilidade das sentenças declaratórias - de acordo com o art. 515 do CPC - é que a atividade cognitiva esteja completa a respeito da existência de todos os elementos da norma jurídica individualizada, e nem todas as sentenças declaratórias que julgam improcedentes a demanda de inexistência da obrigação podem ser exequíveis, pois pode ocorrer de não apresentarem sua atividade cognitiva completa.

O nosso sistema processual, ao avesso do que ocorre com a matéria de defesa, a qual deve se concentrar na contestação (art. 336, CPC/15), alberga a regra da substanciação, atinente à causa de pedir. Não há, portanto, norma que imponha a concentração, na petição inicial, de todas as causas de pedir relacionadas ao mesmo pedido (inexigibilidade ou inexistência), pois o princípio da eventualidade não se aplica ao autor, não se exigindo dele que alegue todas as causas de pedir que fundamentam seu pedido na petição inicial.

O conteúdo da sentença de improcedência de demanda declaratória de inexistência de obrigação apenas se manifestará sobre aquela específica causa de pedir. Desse modo, a sentença que julga improcedente uma ação declaratória negativa de inexistência da relação jurídica será uma sentença declaratória positiva de improcedência da ação declaratória negativa, que se limitará a negar a existência do direito consubstanciado naquela causa de pedir, o que significa que, alterada a causa petendi, a inexistência da obrigação poderá ser fundamento de outra demanda declaratória negativa, podendo ser que não se mantenha o mesmo juízo positivo de improcedência.

59 ZAVASCKI, 2012, p. 18

60 “(...) 1. A jurisprudência deste Tribunal orienta que "não retira a liquidez do título, possível julgamento de ação revisional do contrato originário, demandando-se, apenas, adequação da execução ao montante apurado na ação revisional” (...). 2. Ademais, "a sentença declaratória em ação de revisão de contrato pode ser executada pelo réu, mesmo sem ter havido reconvenção, tendo em vista a presença dos elementos suficientes à execução, o caráter de "duplicidade" dessas ações, e os princípios da economia, da efetividade e da duração razoável do processo (...)" (EDcl no AgInt no REsp 1277669/SP, Rel. Ministra Maria Isabel Gallotti, 4a T., DJe 01/08/2018)

61 THEODORO JÚNIOR, 2017, p. 29-33; SANTOS, 2017, p. 30 
Logo, nem todas as sentenças declaratórias positivas proferidas que julgam improcedentes devem ser consideradas títulos executivos porque existem aquelas cuja atividade cognitiva não está completa deixando algum resíduo a ensejar uma nova ação de conhecimento.

Por exemplo, a sentença declaratória negativa de inexistência de obrigação proposta pela ocorrência de uma nulidade fará coisa julgada exclusivamente nos limites dessa causa de pedir, mas a parte pode ingressar com nova ação declaratória pelo mesmo objeto, alterando a causa de pedir, alegando, por exemplo, a inconstitucionalidade da lei.

Aliás, conforme afirmou Teori Zavaski a executividade das sentenças declaratórias decorre "da circunstância de se tratar de sentença que traz identificação completa de uma norma jurídica individualizada", pois quando isso ocorre "é porque a fase cognitiva está integralmente atendida" ${ }^{62}$. Ora, se existe algum resíduo a ensejar nova ação de conhecimento é porque a atividade cognitiva não está completa; logo, nem todas as sentenças declaratórias positivas proferidas quando o juiz julga improcedente uma ação declaratória negativa devem ser consideradas títulos executivos.

Observa-se que a eficácia preclusiva da coisa julgada (art. 508, CPC/15 e art. 474, CPC/73) somente atingirá os argumentos referentes à causa de pedir entre as partes daquela demanda, não irá atingir todas as possíveis causas de pedir relacionadas a mesma "ação", uma vez que outro fato jurídico ou outra fundamentação jurídica, ensejarão outra demanda, considerando-se tratar de nova causa de pedir.

A se entender de outro modo, ficaria difícil interpretar o art. 525, $\mathbb{S} 1^{\circ}$, VII do CPC quando estabelece que o executado poderá alegar na impugnação ao cumprimento da sentença "qualquer causa modificativa ou extintiva da obrigação, como pagamento, novação, compensação, transação ou prescrição, desde que supervenientes à sentença”.

Este dispositivo exclui dos possíveis fundamentos da impugnação ao cumprimento da sentença toda e qualquer causa modificativa, extintiva ou impeditiva da obrigação, anteriores à sentença, porque a decisão, objeto do cumprimento da sentença, foi atingida pela coisa julgada, que, pelos limites da eficácia preclusiva, só pode atingir a causa de pedir objeto daquela decisão. Vê-se que o executado não pode alegar, em sede de defesa, matéria que poderia ter sido causa de pedir na fase de conhecimento, mas não foi alegada.

Admitir que toda sentença de improcedência proferida numa ação meramente declaratória de inexistência de obrigação é um título executivo judicial em favor do réu, em face da sua duplicidade, seria abrir uma antinomia no sistema, uma vez que o art. 525, $\mathbb{S} 1^{\circ}$, VII do CPC, veda ao executado alegar em sua defesa

62 ZAVASCKI, 2012, p. 18. 
os fatos anteriores à sentença que não estão cobertos pela coisa julgada material. Isto é, seria admitir o cumprimento de uma sentença (que não chegou a se manifestar sobre a causa de pedir), e, ao mesmo tempo, impedir a defesa, na fase de impugnação ao cumprimento da sentença, daquela mesma causa de pedir. Em suma, o exequente pode ser executado, mas estaria impedido de alegar tais fatos em sua defesa, embora eles não estivessem cobertos pela coisa julgada material.

Nesse sentido, a preocupação de Daniel Assunção:

Confesso que tenho certa resistência em admitir que a sentença de improcedência proferida numa ação meramente declaratória de inexistência de débito, ao declarar a existência de uma obrigação inadimplida em razão da natureza dúplice dessa espécie de ação, seja um título executivo judicial em favor do réu. Minha resistência diz respeito à limitação das matérias alegáveis num eventual cumprimento de sentença, porque o autor não tem o dever de cumular em sua petição inicial todas as causas de pedir, não sendo a ele aplicável o princípio da eventualidade existente para o réu e consagrado nos arts. 336 e 342 do Novo CPC.

A demonstração mais cabal de que em nosso sistema não se aplica o princípio da eventualidade ao autor, exigindo-se dele a alegação de todas as causas de pedir que fundamentam seu pedido na petição inicial vem do art. 1.072, VI, do Novo CPC, que revogou a única norma nesse sentido, existente no art. 98, $\mathbb{S} 4^{\circ}$, da Lei 12.529/2011 (Lei de Defesa da Concorrência).

Não me parece viável impedir que o executado nessas circunstâncias alegue matéria em sede de defesa que poderia ter sido causa de pedir na fase de conhecimento, mas não foi alegada. E nem se fale em eficácia preclusiva da coisa julgada, considerando-se que a eficácia preclusiva da coisa julgada atinge tão somente as alegações referentes à causa de pedir que fez parte da primeira demanda, porquanto alegado outro fato jurídico ou outra fundamentação jurídica, não presentes na primeira demanda, afasta-se do caso concreto a tríplice identidade, considerando-se tratar de nova causa de pedir ${ }^{63}$.

E continua o autor, trazendo um exemplo para ilustrar seu posicionamento:

Tomo um exemplo para concretizar meus receios. O consumidor ingressa com ação alegando não ser devedor de determinado valor por ter encerrado sua conta-corrente. A ação é julgada improcedente, o que, pelo aspecto apenas do pedido, significa que o consumidor é devedor do valor cobrado. Ocorre, entretanto, que o consumidor não alegou a abusividade dos juros cobrados, a ilegalidade das taxas e outras matérias que poderiam tutelá-lo. Uma vez que a instituição financeira inicie o cumprimento de sentença, essas matérias não poderão ser alegadas em sua defesa, considerando a limitação cognitiva dessa defesa imposta pelo art. 525, $\mathbb{S} 1^{\circ}{ }^{\circ}$, do Novo $\mathrm{CPC}^{64}$.

Ao exemplo trazido pelo autor, pode-se ainda acrescentar outros. Imagine-se uma sentença que julga improcedente uma ação declaratória negativa de débito fiscal em razão da nulidade do auto de infração; a coisa julgada recairá sobre esta específica causa de pedir, mas o autor poderá voltar a pedir uma nova

63 NEVES, 2018, p. 1.112.

64 NEVES, 2018, p. 1.112 
ação declaratória pelo mesmo objeto alegando a inconstitucionalidade da lei proposta pela receita para fazer valer o seu direito. Também se pode imaginar a hipótese de uma sentença que julga improcedente a ação declaratória de um negócio jurídico proposta em face da ilicitude do objeto; a coisa julgada material não impedirá nova demanda de declaração de nulidade do mesmo contrato com fundamento na incapacidade absoluta do agente.

Enfim, se a sentença de improcedência de demanda declaratória de inexistência da obrigação pode não ter atingido todas as possíveis causas de pedir relacionadas à mesma demanda, e se o sistema processual não admite que na fase de cumprimento de sentença que julga improcedente uma ação meramente declaratória o executado argua na sua impugnação fatos anteriores a tal sentença, a conclusão não pode ser outra: nem toda sentença de improcedência de demanda declaratória de inexistência da obrigação é título executivo judicial porque não se pode admitir a executividade de uma sentença que não chegou a examinar todos os aspectos da existência ou inexistência direito exequendo e ao mesmo tempo limitar a admissibilidade da impugnação ao cumprimento de sentença (art. $525, \mathbb{S} 1^{\circ}$, VII do CPC), pois consistiria em violação à garantia do devido processo legal.

\section{CONCLUSÃO}

O CPC de 2015, ao reconhecer no seu art. 515, I, como título executivo todas "as decisões proferidas no processo civil que reconheçam a exigibilidade de obrigação de pagar quantia, de fazer, de não fazer ou de entregar coisa", acolheu entendimento que já vinha se consolidando no regime do Código anterior, segundo o qual a sentença meramente declaratória é título executivo judicial, por expressa determinação legal, desde que reconheça a exigibilidade de uma obrigação, pois sua executividade decorre da circunstância da trazer a identificação completa de uma norma jurídica individualizada, significando que a fase cognitiva está integralmente atendida.

Diante desse entendimento, o STJ (REsp 1.324.152/SP - Tema 899), afirmou que "a sentença, qualquer que seja sua natureza, seja de procedência ou improcedência do pedido, constitui título executivo judicial, desde que estabeleça obrigação de pagar quantia, de fazer, não fazer ou entregar coisa”.

Contudo, não se pode afirmar que toda a sentença de improcedência de demanda declaratória de inexistência de obrigação seja título executivo judicial, porque a eficácia executiva não será determinada apenas pelo reconhecimento de todos os elementos identificadores da obrigação, mas será necessário analisar se a duplicidade da ação declaratória no tocante à inexistência do direito afirmado pelo autor dá ao demandado tutela de igual qualidade à que concederia ao autor no caso de procedência da demanda, à luz daquela causa de pedir. 
O nosso sistema processual não se exige do autor a alegação de todas as causas de pedir que fundamentam seu pedido na petição inicial. Desse modo, a sentença que julga improcedente uma ação declaratória negativa de inexistência da relação jurídica será uma sentença declaratória positiva de improcedência da ação declaratória negativa, que se limitará a negar a existência do direito consubstanciado naquela causa de pedir, o que significa que, alterada a causa petendi, a inexistência da obrigação poderá ser fundamento de outra demanda declaratória negativa, podendo ser que não se mantenha o mesmo juízo positivo de improcedência.

Por sua vez, se a eficácia preclusiva da coisa julgada somente atingirá os argumentos referentes à causa de pedir entre as partes daquela demanda, admitir que toda sentença de improcedência proferida numa ação meramente declaratória de inexistência de obrigação seja título executivo judicial em favor do réu, permitiria abrir uma antinomia no sistema, uma vez que o art. $525, \mathbb{S} 1^{\circ}$, VII do CPC, veda ao executado alegar em sua defesa os fatos anteriores à sentença que não estão cobertos pela coisa julgada material. Isto é, seria admitir a execução da sentença (que não chegou a se manifestar sobre a causa de pedir), e, ao mesmo tempo, impedir a defesa, na fase de impugnação ao cumprimento da sentença, daquela mesma causa de pedir.

Enfim, se a sentença de improcedência de demanda declaratória de inexistência da obrigação pode não ter atingido todas as possíveis causas de pedir relacionadas à mesma demanda, e se o sistema processual não admite que na fase de cumprimento de sentença que julga improcedente uma ação meramente declaratória o executado argua na sua impugnação fatos anteriores a tal sentença, a conclusão não pode ser outra: nem toda sentença de improcedência de demanda declaratória de inexistência da obrigação é título executivo judicial porque não se pode admitir a executividade de uma sentença que não chegou a examinar todos os aspectos da existência ou inexistência direito exequendo e ao mesmo tempo limitar a admissibilidade da impugnação ao cumprimento de sentença (art. 525, $\mathbb{S} 1^{\circ}$, VII do CPC), pois consistiria em violação à garantia do devido processo legal.

\section{REFERÊNCIAS}

ASSIS, Araken de. Cumulação de ações. 3 ed. São Paulo: RT, 1998.

ASSIS, Araken de. Procedimento sumário. São Paulo: Malheiros, 1996.

BARBI, Celso Agrícola. Ação declaratória principal e incidente. 7 ed., Rio de Janeiro, Forense, 1996.

BONDIOLI, Luiz Guilherme Aidar. O novo CPC: a terceira etapa da reforma. São Paulo: Saraiva, 2006. 
BONDIOLI, Luiz Guilherme Aidar. Reconvenção no processo civil. São Paulo: Saraiva, 2009.

CARNEIRO, Athos Gusmão. Cumprimento da sentença civil. Rio de Janeiro: Forense, 2007.

CARNELUTTI, Francesco. Derecho y processo. v. 1. Trad. Santiago Sentis Melendo. Buenos Aires: Europa-America, 1971.

CHIOVENDA, Giuseppe. Istituzioni di diritto processuale civile, vol I. 2 ed., Napoli: Casa editrice Dott. Eugenio Jovene, 1960.

DEMARCHI, Juliana.. Ações dúplices, pedido contraposto e reconvenção. In: DIDIER JR., Fredie (org) Leituras complementares de processo civil. 8 ed., Salvador: Juspodvim, pp. 347-368, 2010.

DIDIER JR., Fredie. Curso de direito processual civil: introdução ao direito processual civil, parte geral e processo de conhecimento. 19. ed.. Salvador: JusPodivm, 2017.

DIDIER JR., Fredie; CUNHA, Leonardo José Carneiro da; BRAGA, Paula Sarno; OLIVEIRA: Rafael. Curso de Direito Processual Civil: Execução, v. 5.7 ed. Salvador: JusPodivm, 2017.

JORGE, Flávio Cheim; DIDIER JR, Fredie; e RODRIGUES, Marcelo Abelha. A terceira etapa da reforma processual civil. São Paulo: Saraiva, 2006.

KNIJNIK, Danilo. A nova execução. In: OLIVEIRA, Carlos Alberto Alvaro de (org.). A nova execução. Comentários à Lei 11.232/2005. Rio de Janeiro: Forense, p. 145-166, 2006.

LIEBMAN, Enrico Tullio. Manuale di diritto processuale civile. 5 ed., Milano, Giuffrè, 1992.

LOPES, João Batista. Ação declaratória. 4 ed., São Paulo: Revista dos Tribunais, 1995.

LUCON, P. H. S. . Coisa julgada, efeitos da sentença, coisa julgada inconstitucional e embargos à execução do art. 741, parágrafo único. Revista do Advogado. São Paulo, v. 84, pp. 145-167, 2005.

MARCATO, Antônio Carlos. Código de processo civil interpretado. 3 ed. São Paulo: Atlas, 2008.

MATTOS, Sérgio Luís Wetzel de. Comentários ao art. 475-N do CPC. In: OLIVEIRA, Carlos Alberto Alvaro de (org.). A nova execução. Comentários à Lei 11.232/2005. Rio de Janeiro: Forense, p. 167-185, 2006.

MOUZALAS, Rinaldo. Duplicidade da ação declaratória. Revista de Processo. São Paulo, v. 237, pp. 115-134, 2014 a. 
MOUZALAS, Rinaldo. Sentenças de improcedência: apresentação e análise dos principais argumentos favoráveis e contrários à sua executividade. Revista de processo. São Paulo, v. 232, pp. 121-165, 2014 b.

NEVES, Daniel Amorim Assumpção. Manual de Direito Processual Civil. 10 ed. Salvador: JusPodivm. 2018.

PONTES DE MIRANDA, Francisco Cavalcante. Tratado das ações, t. I, São Paulo: Revista dos Tribunais, 1976.

SANTOS, Ernani Fidélis dos. As reformas de 2005 do Código de Processo Civil. São Paulo: Saraiva, 2006.

SANTOS, Ernani Fidelis dos. Manual de direito processual civil, volume 2: cumprimento da sentença e processo de execução. 16. ed. São Paulo : Saraiva, 2017.

SICA, Heitor Vitor Mendonça. Tutela meramente declaratória vista pela jurisprudência do STJ. Isabel Galotti; Bruno Dantas; Alexandre Freire; Fernando da Fonseca Gajardoni; José Miguel Garcia Medina (Org.). O papel da jurisprudência no STJ. v. 1. São Paulo: RT, pp. 447-455, 2014.

SILVA, Ovídio A. Batista da. Curso de Processo Civil. v. I - Processo de Conhecimento. 3 ed., Porto Alegre, Fabris, 1996.

TALAMINI, Eduardo. Sentença que reconhece obrigação como título executivo - art.475-N, I, acrescido pela lei 11.232/2005. Revista Jurídica, v. 54, n. 344, p. 19-43, jun. 2006

THEODORO JÚNIOR, Humberto. Coisa julgada, ação declaratória seguida de condenatória. Revista de Processo. São Paulo, v. 81, pp 82-97, jan-mar 1996.

THEODORO JÚNIOR, Humberto. Curso de Direito Processual Civil. v. 3.50 ed. Rio de Janeiro: Forense, 2017.

TORNAGHI, Hélio, Comentários ao código de processo civil, vol I - arts, 1o. a 153. São Paulo, Revista dos Tribunais, 1974.

WAMBIER, Luiz Rodrigues; WAMBIER, Teresa Arruda Alvim; e MEDINA, José Miguel Garcia. Breves Comentários à nova sistemática processual civil. São Paulo: Revista dos Tribunais, 2006.

WAMBIER, Teresa Arruda Alvim, DIDIER JR., Fredie; TALAMINI, Eduardo; DANTAS, Bruno. Breves comentários ao novo Código de Processo Civil. São Paulo: RT, 2015.

WAMBIER, Teresa Arruda Alvim; CONCEIÇÃO, Maria Lúcia Lins; RIBEIRO, Leonardo Ferres da Silva; MELLO, Rogério Licastro Torres de. Primeiros comentários ao Novo Código de Processo Civil artigo por artigo. São Paulo, 2016. 
REFLEXÕES ACERCA DA EXECUTIVIDADE DAS SENTENÇAS DE IMPROCEDÊNCIA...

ZAVASCK, Teori. Sentenças declaratórias, sentenças condenatórias e eficácia executiva dos julgados. Revista de Processo. São Paulo, v. 17, n. 109, p. 45-56, mar. 2003b.

ZAVASCKI, Teori. Executividade das sentenças de improcedência em ações declaratórias negativas. Revista de Processo. São Paulo, v. 208, pp. 13-20, 2012.

ZAVASCKI, Teori. Sentenças declaratórias, sentenças condenatórias e eficácia executiva dos julgados. Revista da Faculdade de Direito da UFRGS. Porto Alegre, v. 23, p. 219-230, 2003a.

Recebido em: 15/04/2019.

Aprovado em: 29/11/2019. 